\section{Biological Tissue Response to a New Formulation of a Silicone Based Endodontic Sealer}

Flávia Emi Razera Baldasso ${ }^{1}$, Patrícia Maria Poli Kopper ${ }^{1}$, Renata Dornelles Morgental2 ${ }^{2}$ Liviu Steier ${ }^{3}$, José Antônio Poli de Figueiredo ${ }^{4}$, Roberta Kochenborger Scarparo ${ }^{1}$

\begin{abstract}
Satisfactory biological behavior is a necessary requirement for clinical application of endodontic materials. In this study, the connective tissue responses to silicone (GuttaFlow 2), epoxy resin (AH Plus) and zinc oxide and eugenol (Endofill) based sealers were compared. Twelve Wistar rats had polyethylene tubes (four per animal) containing one of the tested sealers and empty tubes (negative control) implanted in their subcutaneous tissue. The tubes were randomly placed $2 \mathrm{~cm}$ from the spine and at least $2 \mathrm{~cm}$ apart from one another. Tissue samples with implants were processed for histological analysis after 7 or 60 days $(\mathrm{n}=6$ animals per period). Inflammatory cells, fibrous condensation and abscess were scored according to their intensity. Friedman, followed by Dunn's post hoc, was used to compare sealers. Differences between the two experimental periods were verified using Mann-Witney $U$ test $(p<0.05)$. At 7 days, most of the histological parameters showed no significant differences amongst groups. Endofill group scored higher than the others for giant cells $(0<0.05)$ and promoted a greater number of samples presenting abscess formation. GuttaFlow 2 tended to show a less intense inflammatory infiltrate compared to the other materials. At 60 days, there were no significant differences between groups in most of the histological parameters evaluated. However, it was observed that Endofill scored higher for macrophages $(p<0.05)$ compared to the control group, and GuttaFlow 2 tended to present lower scores than the others for neutrophils and abscess. GuttaFlow 2 showed proper biological behavior and should be considered adequate for clinical practice.
\end{abstract}

\author{
'Department of Conservative \\ Dentistry, Dental School, UFRS - \\ Universidade Federal do Rio Grande \\ do Sul, Porto Alegre, RS, Brazil \\ ${ }^{2}$ Department of Stomatology, \\ Dental School, UFSM - \\ Universidade Federal de Santa \\ Maria, Santa Maria, RS, Brazil \\ ${ }^{3}$ Warwick Medical School, University \\ of Warwick, Warwick, United Kingdom \\ ${ }^{4}$ Clinical Department, Dental School, \\ PUCRS - Pontifícia Universidade \\ Católica do Rio Grande do Sul, \\ Porto Alegre, RS, Brazi
}

Correspondence: Roberta Kochenborger Scarparo, Rua Ramiro Barcelos, 2492, 90035003 Porto Alegre, RS, Brasil. Tel: +55-51-3308-5191. email: robertascarparo@hotmail.com

Key Words: GuttaFlow 2, tissue compatibility, root canal filling, endodontic sealers

\section{Introduction}

Endodontic sealers act as union agents between guttapercha and root canal walls, and must be able to fill gaps not reached by the solid obturation material $(1,2)$. Besides presenting adequate physical properties, satisfactory biological behavior is a necessary requirement for their clinical application. These materials are often in direct contact with apical and periapical tissues and should allow, or even stimulate, the deposition of cementum, leading to biological seal and healing process (3).

Several chemical compositions have been suggested for improving endodontic sealers performance, including zinc and oxide (i.e EndoFill), resin (i.e AH Plus) and siliconebased materials (i.e GuttaFlow). Zinc and oxide and eugenol based sealers are still widely employed due to its low cost and acceptable physical/chemical and biological properties (4-5), while AH Plus presents better behavior and has been recognized as a gold standard amongst endodontic sealers, considering its sealing capacity, physical/chemical and biological properties (5-6). Among the silicone-based sealers, GuttaFlow was developed to enhance physical characteristics, such as porosity, flow and adhesion to the root canal walls (7-8). It consists of a matrix of polydimethylsiloxane filled with gutta-percha powder and nanosilver particles (9-10), having unique sealing properties due to its insolubility, expanding post-setting and excellent flow ability (9-11). Recently, the sealer formulation was modified and GuttaFlow 2 was introduced. Its composition is basically the same of the original product, but nanosilver particles were replaced by micro-silver particles (11-12). The evaluation of GuttaFlow new formulation is necessary since the biological effects of silver particles depends on its size and surface that are in contact with tissues (13-14). As a matter of fact, it was found that silver microparticles present a smaller number of atoms in their surface comparing to silver nanoparticles (13-14), which resulted in reduced in vitro toxicity (15). Thus, it was possible that particles with different size presented better biological responses in contact with connective tissue.

Therefore, biological tissue response against this material needs to be further elucidated. Although studies of cytotoxicity have indicated favorable biological potential of both GuttaFlow and GuttaFlow 2 (16), up to date, only the original formulation of GuttaFlow was investigated regarding tissue responses in animal models $(17,18)$. 
Therefore, the aim of the present study was to analyze the connective tissue reactions of Wistar rats to a siliconebased sealer (GuttaFlow 2; Roeko, Coltene Whaledent, Langenau, Germany) compared with a zinc oxide-based sealer (EndoFill; Dentsply Industria e Comerico Ltda, Petropolis, Brazil) and an epoxy resin-based material (AH Plus; Dentsply DeTrey GmbH, Konstanz, Germany).

\section{Material and Methods}

The study protocol was approved by Pontifical Catholic University of Rio Grande do Sul (PUCRS) Animal Care and Use Committees (Protocol 13/00361), Porto Alegre, Brazil. Twelve male Wistar rats, weighing 180 to 220 grams and aging 3 to 4 months, were used in this study. The sample size was determined based on previous investigations data (19-20). The inflammatory reactions to GuttaFlow 2, AH Plus, and EndoFill were evaluated after experimental periods of 7 and 60 days ( $n=6$ per period), aiming to observe if the tissue responses to the materials are temporary or if they produce a long-lasting inflammation. The sealers were inserted into autoclaved polyethylene tubes $(10 \mathrm{~mm}$ long and $1.5 \mathrm{~mm}$ in diameter -Abbott Laboratórios do Brasil, São Paulo, Brazil) to be implanted in the animals' dorsal subcutaneous tissue. The negative control group consisted of empty polyethylene tubes.

The animals were anesthetized by intraperitoneal administration of $0.008 \mathrm{~mL} / 100 \mathrm{~g}$ ketamine (Virbac do and $0.004 \mathrm{~mL} / 100 \mathrm{~g} 2 \%$ xylazine hydrochloride (Virbac do Brasil Industria e Comércio Ltda, São Paulo, SP, Brazil). After disinfection with an alcohol-iodine solution, dorsal trichotomy was manually performed in an area comprising approximately $10 \mathrm{~cm}^{2}$. Four $0.5-\mathrm{cm}$-long incisions were made in the animals' backs $2 \mathrm{~cm}$ from the spine and at least $2 \mathrm{~cm}$ apart from one another. Subcutaneous tissue was divulsed with rhombic point scissors and provided 4 surgical cavities displayed in quadrants equidistant from the center of the animals' backs.

The materials were prepared according to the manufacturers' instructions and introduced into their respective tubes using sterile insulin syringes (Injex Indústria Cirúrgica Ltda, Ourinhos, SP, Brazil). The tubes filled with the materials were inserted in standardized locations into the surgical cavities parallel to the incision. Then, suture was performed using a 3-0 silk thread (Johnson \& Johnson Produtos Profissionais Ltda, São José dos Campos, SP, Brazil).

The animals were euthanized by isoflurane inhalation 7 and 60 days following experimental procedures. Skin segments and subcutaneous tissue samples with implants were removed, placed on cardboard and fixed in 10\% formalin for $24 \mathrm{~h}$. The samples were then processed for paraffin embedding. Slides containing 3 to $4-\mu \mathrm{m}$ thick, semi-serial sections taken parallel to the long axis of the implant region, were prepared to observe both ends of the tube, and stained with hematoxylin-eosin. A calibrated single-blinded examiner assessed the slices at light microscope (Model Lambda LOT 2; ATTO Instruments Co, Hong Kong, China) using 40, 100, 200, and 400 magnifications (kappa $>0.6$ for all evaluated variables).

Examinations at the area adjacent to the polyethylene tube where the sealer was introduced were performed according to the criteria described in previous investigations $(19,20)$. Briefly, cellular events of inflammation (regarding the presence of neutrophils, lymphocytes, macrophages, eosinophils and giant cells) were classified according to the following scale: 1) absent: cells was either absent or within blood vessels, 2) mild: cells were present although sparse or in reduced clusters, 3) moderate: cells were present but did not dominate the microscopic field, and 4) intense: cells were present in the form of an infiltrate close to the material used. Fiber condensation was classified according to the following scale: 1) absence of collagen fibers, 2) presence of a thin layer of collagen fibers, and 3) presence of a thick layer of collagen fibers. Abscess formation was classified as follows: 1) absence of abscess, 2) presence of abscess in contact with the surgical cavity where the material had been inserted, and 3) presence of abscess areas far from the surgical cavity where the material had been inserted.

Friedman, followed by Dunn's post hoc, was used to compare sealers. Differences between the two experimental periods were verified in each group using Mann-Witney U test. The significance level was set at 0.05 .

\section{Results}

Four specimens were excluded from analysis due to fails in the histological preparation. The study results are summarized in Figure 1 and in Table 1. At 7 days, Endofill group scored higher than the others for giant cells $(p<0.05)$ (Fig. 2A). For all other histological parameters, there were no significant differences amongst groups (Fig. 1). Even though, a greater number of samples of EndoFill group presented abscess formation (Fig. 2B), while GuttaFlow 2 tended to show a less intense inflammatory infiltrate compared to the other materials (Fig. 2C). At 60 days, EndoFill scored higher for macrophages compared to the control group $(p<0.05)$, and there were no other significant differences amongst groups. However, GuttaFlow 2 (Fig. $3 A$ ) tended to present less neutrophils and abscess than the other sealers. For eosinophils, all groups scored 1, except AH Plus at the 60-days experimental period, in which these cells were observed in a single sample.

Comparing the results between the two evaluated periods (Fig. 1), all groups showed a decreased presence 
of lymphocytes, macrophages, neutrophils and abscess along the experiment. These differences were statistically significant in the analysis of the variables lymphocytes for the negative control $(p=0.047)$ and for EndoFill $(p=0.023)$, for the variables macrophages for AH Plus $(p=0.010)$ (Fig. $3 \mathrm{~B})$ and EndoFill $(p=0.046)$, and presented a borderline non-significant difference for the variable neutrophils for EndoFill group $(p=0.064)$. For giant cells, Endofill significantly reduced the number over time $(p=0.007)$. All groups increased fiber condensation at the 60-day experimental period, and $\mathrm{AH}$ Plus presented a significant difference ( $p=0.015)$ (Fig. $3 A-C)$.
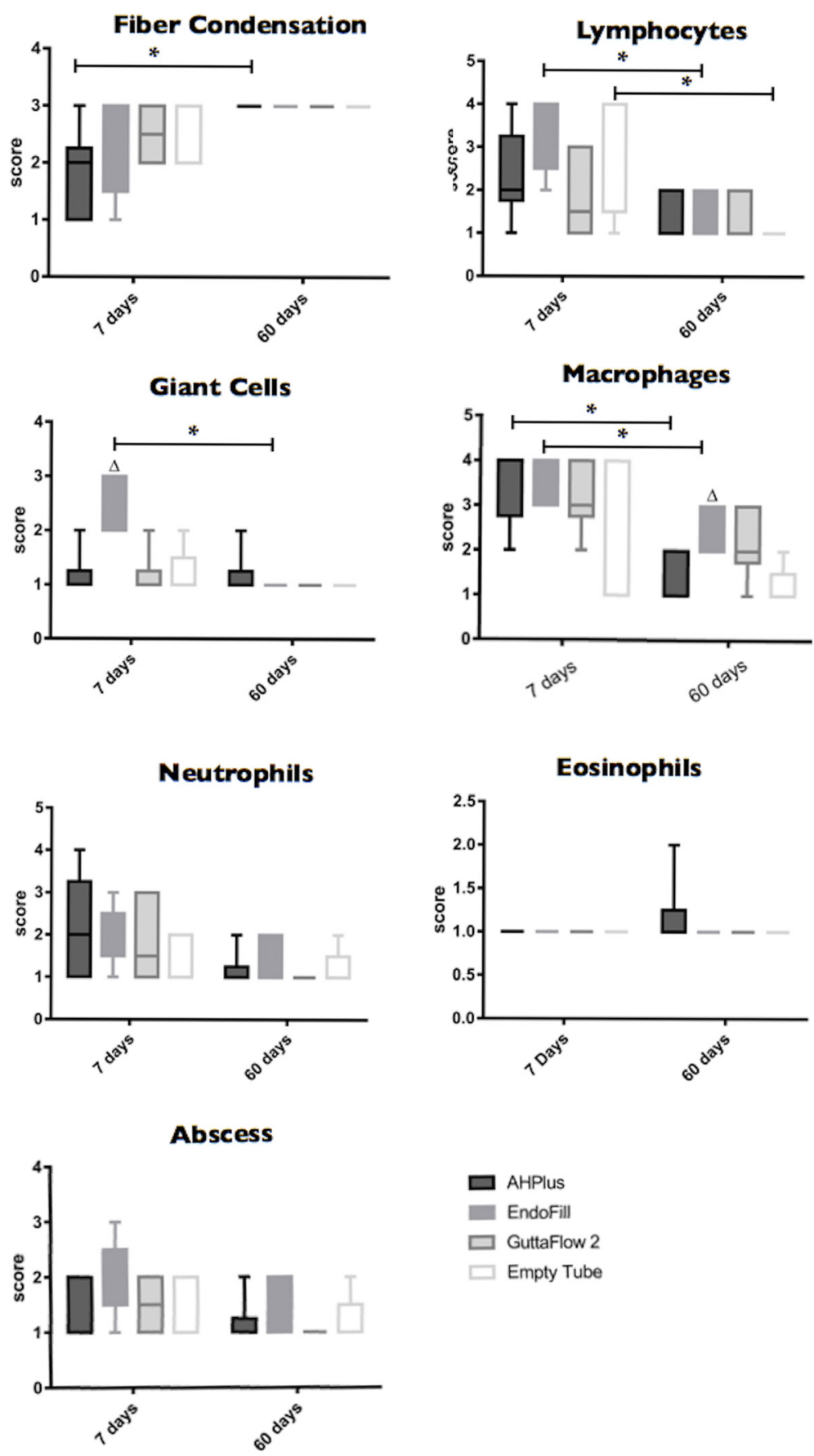

Figure 1. Comparison amongst study groups and between 7 and 60 days experimental periods, regarding the following variables: fibers condensation, lymphocytes, giant cells, macrophages, neutrophils, abscess and eosinophils. EndoFill sealer showed statistically significant higher scores of giant cells comparing to the other groups $(\triangle \mathrm{PO}<0.05)$ at the 7 -days period, and higher scores for macrophages compared to the control group at the 60-days period $(\triangle \mathrm{P} 0<0.05)$. Horizontal bars indicate statistically significant differences in the same material between the two experimental periods $\left({ }^{*} \mathrm{P} 0<0.05\right)$. 
Table 1. Percentage of samples per score in the study groups for the variables fiber condensation. lymphocytes. giant cells. eosinophils. neutrophils. macrophages and abscess.

\begin{tabular}{|c|c|c|c|c|c|}
\hline & Period/Score & AH Plus & EndoFill & GuttaFlow 2 & Empty Tube \\
\hline \multicolumn{6}{|c|}{ Fiber Condensation } \\
\hline \multirow{3}{*}{7 days } & 1 & $33.33 \%$ & $20 \%$ & - & - \\
\hline & 2 & $50 \%$ & $20 \%$ & $50 \%$ & $40 \%$ \\
\hline & 3 & $16.66 \%$ & $60 \%$ & $50 \%$ & $60 \%$ \\
\hline \multirow{3}{*}{60 days } & 1 & - & - & - & - \\
\hline & 2 & - & - & - & - \\
\hline & 3 & $100 \%$ & $100 \%$ & $100 \%$ & $100 \%$ \\
\hline \multicolumn{6}{|l|}{ Lymphocytes } \\
\hline \multirow{4}{*}{7 days } & 1 & $50 \%$ & - & $50 \%$ & $20 \%$ \\
\hline & 2 & $16.66 \%$ & $20 \%$ & $20 \%$ & $20 \%$ \\
\hline & 3 & $16.66 \%$ & $40 \%$ & $40 \%$ & - \\
\hline & 4 & $16.66 \%$ & $40 \%$ & - & $40 \%$ \\
\hline \multirow{4}{*}{60 days } & 1 & $66.66 \%$ & $60 \%$ & $66.66 \%$ & $100 \%$ \\
\hline & 2 & $33.33 \%$ & $40 \%$ & $33.33 \%$ & - \\
\hline & 3 & - & - & - & - \\
\hline & 4 & - & - & - & - \\
\hline \multicolumn{6}{|l|}{ Giant Cells } \\
\hline \multirow{4}{*}{7 days } & 1 & $83.33 \%$ & - & $83.33 \%$ & $80 \%$ \\
\hline & 2 & $16.66 \%$ & $60 \%$ & $16.66 \%$ & $20 \%$ \\
\hline & 3 & - & $40 \%$ & - & - \\
\hline & 4 & - & - & - & - \\
\hline \multirow{4}{*}{60 days } & 1 & $83.33 \%$ & $100 \%$ & $100 \%$ & $100 \%$ \\
\hline & 2 & $16.66 \%$ & - & - & - \\
\hline & 3 & - & - & - & - \\
\hline & 4 & - & - & - & - \\
\hline \multicolumn{6}{|l|}{ Eosinophils } \\
\hline \multirow{4}{*}{7 days } & 1 & $83.33 \%$ & $100 \%$ & $100 \%$ & $100 \%$ \\
\hline & 2 & $16.66 \%$ & - & - & - \\
\hline & 3 & - & - & - & - \\
\hline & 4 & - & - & - & - \\
\hline \multirow{4}{*}{60 days } & 1 & $100 \%$ & $100 \%$ & $100 \%$ & $100 \%$ \\
\hline & 2 & - & - & - & - \\
\hline & 3 & - & - & - & - \\
\hline & 4 & - & - & - & - \\
\hline \multicolumn{6}{|l|}{ Neutrophils } \\
\hline \multirow{4}{*}{7 days } & 1 & $40 \%$ & $20 \%$ & $50 \%$ & $60 \%$ \\
\hline & 2 & $40 \%$ & $60 \%$ & $10 \%$ & $40 \%$ \\
\hline & 3 & $20 \%$ & $20 \%$ & $40 \%$ & - \\
\hline & 4 & $20 \%$ & - & - & - \\
\hline \multirow{4}{*}{60 days } & 1 & $83.33 \%$ & $40 \%$ & $100 \%$ & $80 \%$ \\
\hline & 2 & $16.66 \%$ & $60 \%$ & - & $20 \%$ \\
\hline & 3 & - & - & - & - \\
\hline & 4 & - & - & - & - \\
\hline \multicolumn{6}{|l|}{ Macrophages } \\
\hline & 1 & - & - & - & $40 \%$ \\
\hline 7 dave & 2 & $16.66 \%$ & - & $16.66 \%$ & - \\
\hline Tays & 3 & $16.66 \%$ & $40 \%$ & $50 \%$ & - \\
\hline & 4 & $66.66 \%$ & $60 \%$ & $33.33 \%$ & $60 \%$ \\
\hline & 1 & $33.33 \%$ & - & $16.66 \%$ & $80 \%$ \\
\hline 60 davs & 2 & $66.66 \%$ & $60 \%$ & $50 \%$ & $20 \%$ \\
\hline 00 uays & 3 & - & $40 \%$ & $33.33 \%$ & - \\
\hline & 4 & - & - & - & - \\
\hline Abscess & & & & & \\
\hline & 1 & $66.66 \%$ & $20 \%$ & $50 \%$ & $60 \%$ \\
\hline 7 days & 2 & $33.33 \%$ & $60 \%$ & $50 \%$ & $40 \%$ \\
\hline & 3 & - & $20 \%$ & - & - \\
\hline & 1 & $83.33 \%$ & $60 \%$ & $100 \%$ & $80 \%$ \\
\hline 60 days & 2 & $16.66 \%$ & $40 \%$ & - & $20 \%$ \\
\hline & 3 & - & - & - & - \\
\hline
\end{tabular}



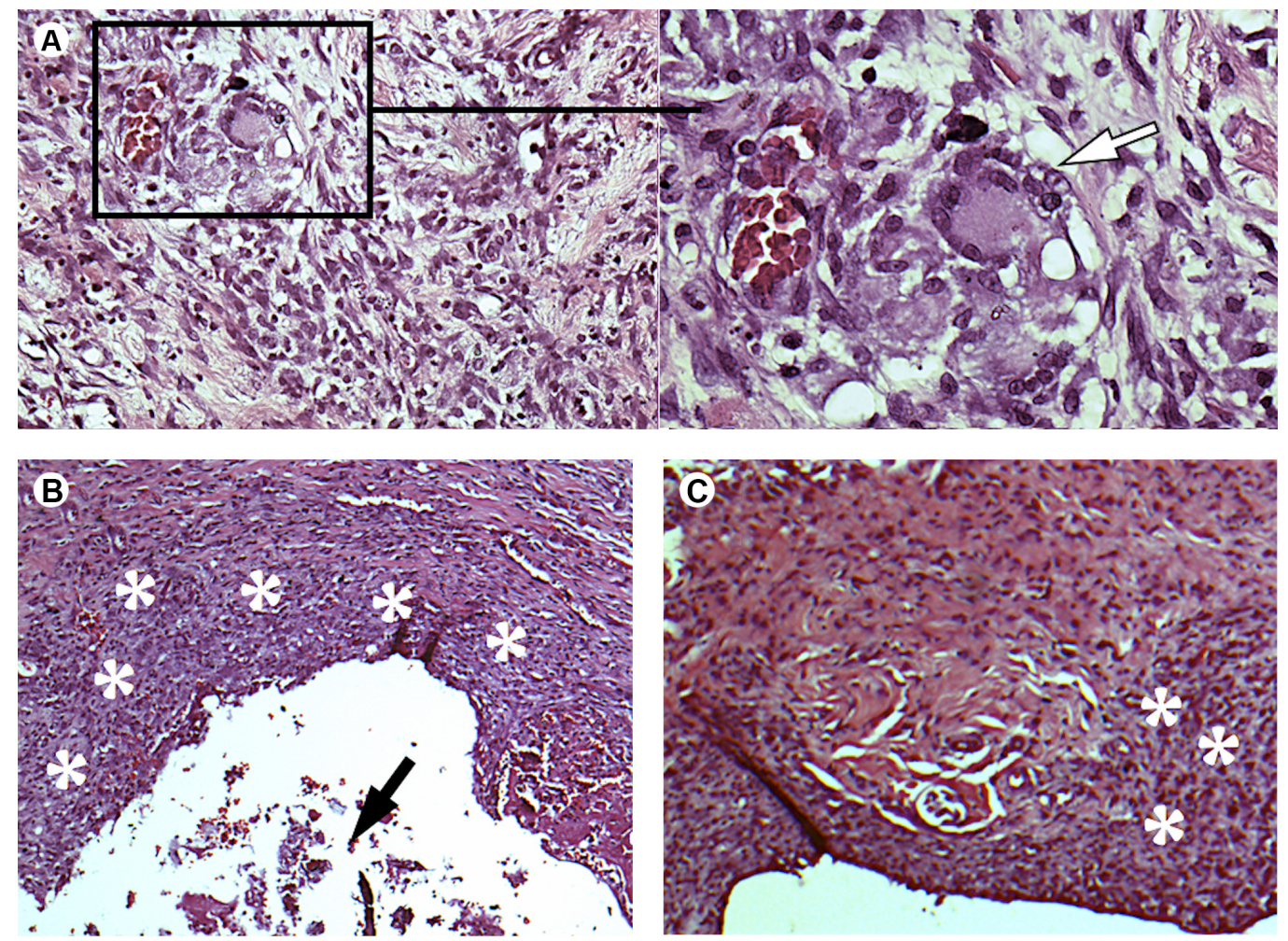

Figure 2. (A) Inflammatory infiltrate observed in response to the zinc and eugenol sealer (EndoFill) after 7 days. Note the presence of giant cell (arrow) - HE, original magnification - 100x and 400x; (B) Intense inflammatory infiltrate (*) presenting abscess formation (arrow) next to the area that contained Endofill sealer at the first experimental period HE, original magnification - 40x; (C) Response to GuttaFlow 2 after 7 days, showing a moderate inflammatory infiltrate $\left.{ }^{*}\right)$ - HE, original magnification - 100x.
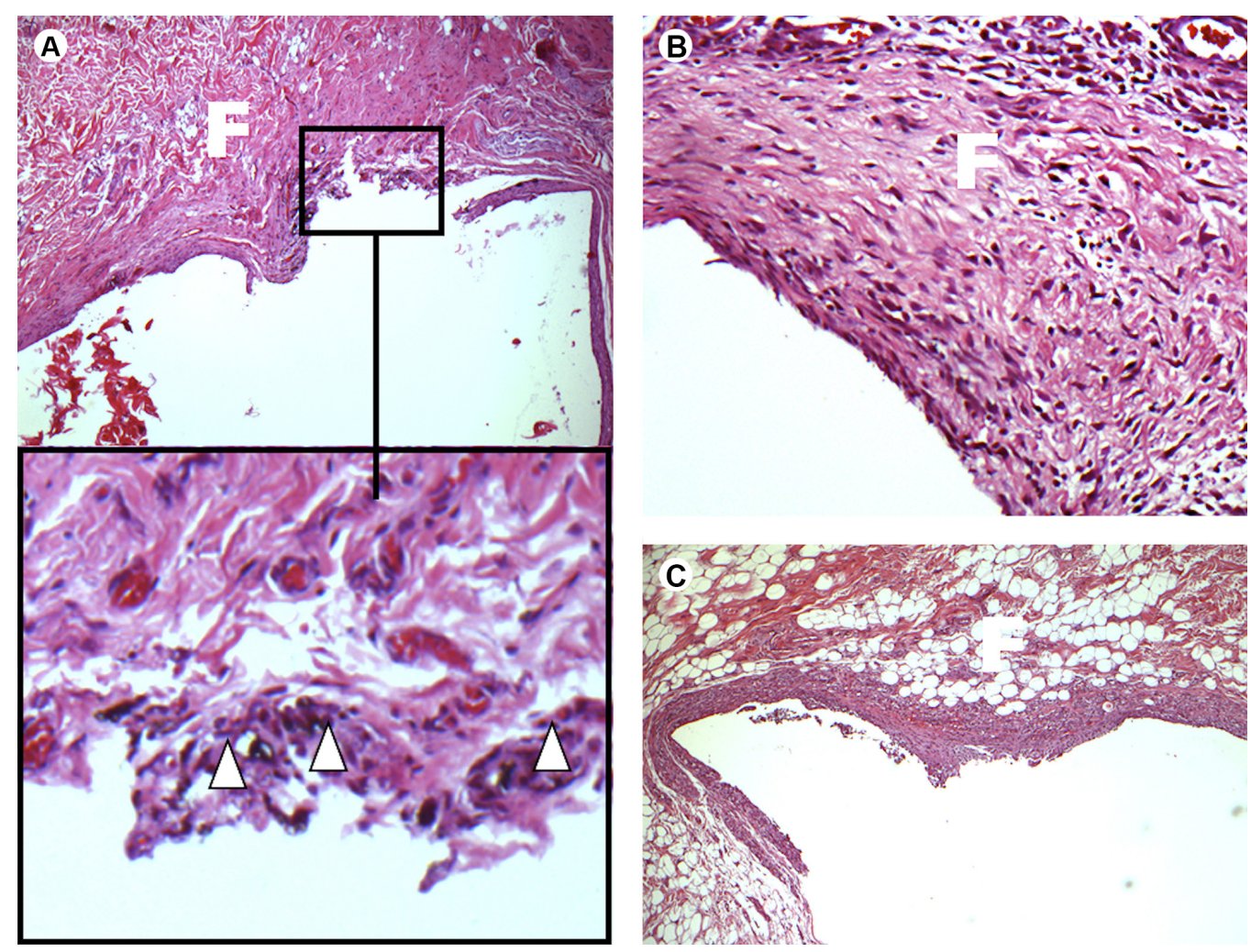

Figure 3. (A) Response to GuttaFlow 2 at the second experimental period, showing macrophages phagocyting the sealer $(\Delta)$ and intense fiber condensation (F) - HE, original magnification - 40x and 400x; For both negative control (B) - HE, original magnification 100x - and AH Plus sealer (C) - HE, original magnification 100x - decreased inflammatory infiltrate and intense fiber condensation (F) were observed. 


\section{Discussion}

In the present study, GuttaFlow 2 caused a tissue reaction similar to that one observed in the negative control, presenting biological potential. When compared to well studied materials, i.e. AH Plus and EndoFill, there were no significant differences in most of the evaluated criteria.

In the 7-day experimental period, a more pronounced presence of giant cells was observed in response to EndoFill. According to Oliveira Mendes et al. (21), although zinc oxide-eugenol sealers did not interfere with the macrophages' viability, their adherence and phagocytosis are affected in contact with this sealer, which could explain giant cells mobilization to eliminate the material. Moreover, after 60 days, Endofill showed significant higher scores for macrophages compared to the control group and presented a tendency for higher scores of neutrophils and abscess. In this regard, long-lasting acute inflammation is considered undesirable in the evaluation of biocompatibility and zinc oxide and eugenol sealer compounds apparently presented greater potential for tissue irritation (20).

All groups presented lower scores for fiber condensation at the first period, which indicates that tissue reactions became confined along the time, and confirms previous results $(19,20)$. Generally, at the 7 -days period, specimens showed more intense inflammatory responses compared to the 60-days period. This is probably due to the process of tissue repair, since even the empty tubes promoted greater inflammatory intensity in the shortest period of evaluation. Greater scores for lymphocytes and macrophages after 7 days compared to the 60-days period were verified in all groups, being these differences significant for lymphocytes for the negative control group and for macrophages for $\mathrm{AH}$ Plus and EndoFill group. These outcomes are in line with previous studies showing decreased inflammatory response to endodontic sealers along time $(19,20)$.

The tissue reactions promoted by GuttaFlow 2 did not differ from that of $\mathrm{AH}$ Plus - which is considered a gold standard sealer with regards to biocompatibility $(19,20)$ for any of the analyzed variables and at both time periods, which qualifies the silicone-based sealer as a material that presents appropriate biological behavior. Regarding silicone-based sealers, previous studies in cell culture showed similar or lower citotoxicity of both GuttaFlow and GuttaFlow 2 compared to AH Plus (16,22-24). However, animal studies are indispensable to complete material biologic validation $(25,26)$. It allows the assessment of connective tissue reactions to the sealers, mimicking the events that would occur at the apical periodontal ligament. Thus, the present methodology reproduces the reactions of periapical tissues when in contact with sealers in endodontic practice. Within this context, sealers should not induce long-lasting inflammatory or immune responses (27), and only those materials that proved to have an acceptable tissue compatibility should be considered for use (28).

Up to date, no experimental study tested the effects of the new formulation of GuttaFlow in direct contact to connective tissue. Nevertheless, the current results agree with others that show biocompatibility of GuttaFlow original formulation $(17,18)$. This outcome was expected since GuttaFlow 2 presents basically the same composition, and the modified silver microparticles present a smaller number of atoms in their surface compared to nanoparticles $(11,12)$. A previous investigation had confirmed that these features reduce citotoxicity (25).

A possible explanation to GuttaFlow 2 compatibility is its composition. This material contains gutta-percha in powder form, which is recognized as a non-toxic agent. A previous study showed that, although gutta-percha induces inflammation, it does not cause an intense longlasting reaction when in contact to connective tissues (29). As demonstrated herein, the addition of resins, oils, silver particles and other compounds did not result in a more intense inflammatory reaction compared neither to the other tested sealers nor to the negative control.

Taken into account the methodology and the findings presented herein, GuttaFlow 2 showed proper biological behavior and should be considered adequate for clinical practice.

\section{Resumo}

Um dos requisistos para a aplicação clínica de materiais endodônticos é apresentar comportamento biológico satisfatório. Neste estudo, as respostas do tecido conjuntivo a cimentos endodônticos à base de silicone (GuttaFlow 2), resina epóxica (AH Plus) e óxido de zinco e eugenol (Endofill) foram comparadas. Doze ratos Wistar tiveram tubos de polietileno (4 em cada animal) contendo um dos materiais e tubos vazios (controle negativo) implantados no tecido conjuntivo subcutâneo. Os tubos foram randomicamente posicionados pelo menos $2 \mathrm{~cm}$ distantes entre si e da espinha dorsal do animal. Amostras de tecido contendo os implantes foram processadas para análise histológica após 7 e 60 dias ( $n=6$ animais por periodo). Células inflamatórias, condensação fibrosa e formação de abscesso foram classificadas em escores de acordo com sua intensidade. 0 teste Friedman, seguido por post hoc de Dunn, foi empregado para comparar os cimentos. 0 teste de Mann-Witney $U$ foi empregado para verificar diferenças entre os periodos experimentais em cada grupo $(p<0,05)$. Após 7 dias, a maior parte dos parâmetros histológicos não mostrou diferenças estatísticas entre os grupos. 0 cimento Endofill promoveu escores mais altos que os outros materiais para a variável células gigantes $(p<0,05)$, além de apresentar um maior número de amostras com formação de abscesso. 0 GuttaFlow 2 tendeu a apresentar infiltrado inflamatório menos intenso comparado aos outros materiais. Após 60 dias, não houve diferenças estatisticamente significantes entre os grupos na maioria dos parâmetros avaliados. Entretanto, observou-se que o EndoFill apresentou escores mais altos para os macrófagos em comparação ao controle $(p<0,05)$ e que o GuttaFlow 2 apresentou tendência a escores mais baixos que os demais materiais para as variáveis neutrófilos e abscesso. 
0 GuttaFlow 2 apresentou propriedades biológicas apropriadas e pode ser considerado adequado para a prática clínica.

\section{References}

1. Kopper PM, Figueiredo JA, Della Bona A, Vanni JR, Bier CA, Bopp S. Comparative in vivo analysis of the sealing ability of three endodontic sealers in post-prepared root canals. Int Endod J 2003;36:857-863.

2. Kopper PM, Vanni JR, Della Bona A, Figueiredo JA, Porto S. In vivo evaluation of the sealing ability of two endodontic sealers in root canals exposed to the oral environment for 45 and 90 days. J Appl Oral Sci 2006;14:43-48.

3. Silva LA, Barnett F, Pumarola-Sune J, Cañadas PS, Nelson-Filho P, Silva RA. Sealapex Xpress and RealSeal XT feature tissue compatibility in vivo. J Endod 2014;40:1424-1428.

4. Waltimo TM, Boiesen J, Eriksen HM. Ørstavik D. Clinical performance of 3 endodontic sealers. Oral Surg Oral Med Oral Pathol Radiol Endod 2001;92:89-92.

5. Silva RV, Silveira FF, Horta MC, Duarte MAH, Cavenago BC, Morais IG. Filling effectiveness and dentinal penetration of endodontic sealers: a stereo and confocal laser scanning microscopy study. Braz Dent J 2015;26:541-546.

6. Schäfer $E$, Bering $N$, Bürklein S. Selected physicochemical properties of AH Plus, EndoREZ and RealSeal SE root canal sealers. Odontology 2015;103:61-65.

7. Mokeem-Saleh A, Hammad M, Silikas N, Qualtrough A, Watts DC. A laboratory evaluation of the physical and mechanical properties of selected root canal sealers. Int Endod J 2010;43:882-888.

8. Savariz A, Gonzalez-Rodriguez MP, Ferrer-Luque CM. Long-term sealing ability of GuttaFlow versus Ah Plus using different obturation techniques. Med Oral Patol Oral Cir Bucal 2010;15:e936-e941.

9. Kontakiotis EG, Tzanetakis GN, Loizides AL. A I2-month longitudinal in vitro leakage study on a new silicon-based root canal filling material (Gutta-Flow). Oral Surg Oral Med Oral Pathol Oral Radiol Endod 2007;103:854-859.

10. Vasiliadis L, Kodonas K, Economides N, Gogos C, Stavrianos C. Shortand long-term sealing ability of Gutta-flow and AH-Plus using an ex vivo fluid transport model. Int Endod J 2010;43:377-381.

11. Guttaflow instruction for use. Altstatten, Switzerland: Coltene/ Whaledent Inc; 2008.

12. Wainstein $M$, Morgental RD, Waltrick $S B$, Oliveira SD, Vier-Pelisser $\mathrm{FV}$, Figueiredo JAet al.. In vitro antibacterial activity of a siliconebased endodontic sealer and two conventional sealers. Braz Oral Res 2016:30:e18.

13. Cha K, Hong HW, Choi YG, Lee MJ, Park JH, Chae HK, et al.. Comparison of acute responses of mice livers to short-term exposure to nano-sized or micro-sized silver particles. Biotechnol Lett 2008;30:1893-1899.

14. Liu, Guan R, Ye X, Jiaxin Jiang, Mingqi Liu, Guangrong Huang and Xiaoting Chen, et al.. Toxicity of nano- and micro-sized silver particles in human hepatocyte cell line L02. J Physics: Conference Series
2011:304:1-9.

15. Mandal $P$, Zhao J, Sah SK, Huang $Y$, Liu J. In vitro cytotoxicity of guttaflow 2 on human gingival fibroblasts. J Endod 2014;40:11561159.

16. Zoufan K, Jiang J, Komabayashi T, Wang YH, Safavi KE, Zhu O. Cytotoxicity evaluation of Gutta Flow and Endo Sequence BC sealers. Oral Surg Oral Med Oral Pathol Oral Radiol Endod 2011;112:657-661.

17. Gencoglu N, Sener G, Omurtag GZ, Tozan A, Uslu B, Arbak S, et al.. Comparison of biocompatibility and cytotoxicity of two new root canal sealers. Acta Histochem 2010;112:567-575.

18. Ghanaati $S$, Willershausen I, Barbeck M, Unger RE, Joergens M, Sader $\mathrm{RA}$, et al.. Tissue reaction to sealing materials: different view at biocompatibility. Eur J Med Res 2010;15:483-492.

19. Tavares CO, Bottcher DE, Assmann E, Kopper PM, de Figueiredo JA, Grecca FS, et al.. Tissue reactions to a new mineral trioxide aggregatecontaining endodontic sealer. J Endod 2013;39:653-657.

20. Scarparo RK, Grecca FS, Fachin EV. Analysis of tissue reactions to methacrylate resin-based, epoxy resin-based, and zinc oxide-eugenol endodontic sealers. J Endod 2009;35:229-232.

21. Oliveira Mendes ST, Ribeiro Sobrinho AP, Carvalho AT, et al. In vitro evaluation of the cytotoxicity of two root canal sealers on macrophage activity. J Endod 2003;29:95-99.

22. Bouillaguet $\mathrm{S}$, Wataha JC, Tay FR, Brackett MG, Lockwood PE. Initial in vitro biological response to contemporary endodontic sealers. J Endod 2006;32:989-992.

23. Eldeniz AU, Mustafa K, Orstavik D, Dahl JE. Cytotoxicity of new resin-, calcium hydroxide- and silicone-based root canal sealers on fibroblasts derived from human gingiva and L929 cell lines. Int Endod J 2007;40:329-337.

24. Accardo $C$, Himel VT, Lallier TE. A novel GuttaFlow sealer supports cell survival and attachment. J Endod 2014;40:231-234.

25. International Standards Organization. Biological testing of medical and dental materials and devices. Geneve, ISO 10993 Draft; 1991.

26. International Standards Organization. Dentistry - Preclinical evaluantion of medical devices used in dentistry-test methods for dental materials. Geneve, ISO 7405 Draft; 1997.

27. Leonardo MR, Bezerra da Silva LA, Filho MT, Santana da Silva R. Release of formaldehyde by 4 endodontic sealers. Oral Surg Oral Med Oral Pathol Oral Radiol Endod 1999;88:221-225.

28. Hauman $\mathrm{CH}$, Love RM. Biocompatibility of dental materials used in contemporary endodontic therapy: a review. Part 2. Root-canal-filling materials. Int Endod J 2003;36:147-160.

29. Wolfson EM, Seltzer S. Reaction of rat connective tissue to some guttapercha formulations. J Endod 1975;1:395-402.

Received March 7, 2016 Accepted October 6, 2016 